\title{
EVALUATION OF THE SIGNIFICANCE OF LINEAR NON- FOREST WOODY VEGETATION IN THE DEVELOPMENT OF AN ECOLOGICAL NETWORK
}

\author{
DiviAKOVÁ, A. - KoČICKÁ, E. - BELČÁKOVÁ, I.* - BELÁŇOVÁ, E. \\ UNESCO-Chair on Sustainable Development and Ecological Awareness, Faculty of Ecology \\ and Environmental Sciences, Technical University in Zvolen \\ T. G. Masaryka 24, 96053 Zvolen, Slovakia \\ (phone:+421-45-5206-329) \\ *Corresponding author \\ e-mail: belcakova@tuzvo.sk; phone: +421-45-5206-329 \\ (Received 25 $5^{\text {th }}$ Jul 2017; accepted $18^{\text {th }}$ Dec 2017)
}

\begin{abstract}
Non-Forest Woody Vegetation (NFWV) is a very important element of a human environment as well as landscape-ecological stability; it fulfils many major functions. The linear formations of NFVW as elements of ecological networks have a direct impact on the potential of a landscape. International policies and programs constitute a foundation for developing national programs of ecological networks, an example of which is the so-called Territorial System of Ecological Stability (TSES) in Slovakia. Within the existing methodology concept of TSES, however, the issue of NFWV is significantly understated, particularly in evaluations of its features, its functional significance from various points of view, and its measures intended to bring about ecological stability. The aim of this contribution is to present results from a study focused on evaluating the landscape-ecological and biotic significance of linear formations of NFWV based on detailed field research. The model territory is located in central Slovakia in the southeastern part of the Štiavnické vrchy Mountains, near the village of Žibritov.

Keywords: habitat, landscape-ecological stability, functions of vegetation, phytocoenological survey, zoological survey, local level
\end{abstract}

\section{Introduction}

The establishment of ecological networks is currently one of the main objectives of landscape ecology and the protection of the nature and landscapes. These objectives are set out in important international documents such as Agenda 21, the UN Convention on Biological Diversity, the Pan-European Biological and Landscape Diversity Strategy, European Ecological Network (EECONET) under the European program of International Union for Conservation of Nature (IUCN), and the European Landscape Convention. The principles of NATURA 2000 also articulate a need to preserve networks of significant ecosystems. International policies and programs constitute a foundation for developing national programs of ecological networks, an example of which is the so-called Territorial System of Ecological Stability (hereinafter referred to as TSES) in Slovakia (Miklós et al., 2011).

From theoretical and methodological perspectives, TSES is a modern concept of nature conservation and biodiversity that stands on the principles of the protection of natural conditions and life forms, i.e., the protection of geobiodiversity. The whole system can be seen as a network of ecologically significant segments of a landscape, which is efficiently distributed on the basis of functional and spatial criteria, covering biotic, hydrological, soil and relief conditions. It consists of biocentres (providing a food chain and conditions for reproduction, rest and shelter), biocorridors, and buffer 
zones (providing for the overcoming of barriers that isolate them from each other, the exchange of genetic information and the migration of ecosystems, as well as the interaction of different ecosystems with different levels of stability).

Currently, TSES can be considered the most remarkable and noticeable success in the enforcement of ecological principles in the legislation of decisive planning processes. It is therefore undeniably important in the responsible assessment of vegetation, both in detail and according to clearly defined criteria. In the concepts of the existing TSES methodologies, however, the issue of NFWV is significantly understated, particularly evaluations of its features, its functional significance from various points of view, and its measures intended to bring about ecological stability.

NFWV is defined as a permanent stand of a wood species, including a herbaceous layer, which is not a forest, agricultural crops, or part of the greenery of an urban residential area or other urban development in a landscape (Bulír, 1981; Mareček, 2005). It includes both natural elements of vegetation growing in a spontaneous way and artificially created vegetation formations (Bulír, 1987; Machovec, 1994).

Linear formations of NFWV as elements of ecological networks fulfil a number of important functions and have a direct impact on the potential of a landscape. It is therefore undeniably important to assess such vegetation responsibly, both in detail and according to clearly defined criteria. As mentioned above, linear formations of NFWV can mostly be a part of biocorridors. A biocorridor is a dynamic element that is interlinked with biocentres and, as such, it can create a mutually dependent territorial system. The functionality of a biocorridor is determined by many of its features: its length, width, connectivity, shape of edges, number of gaps, etc. At a local level, biocorridors are mostly represented by important linear elements (Löw et al., 1995).

Forman and Godron (1986) divide corridors according to several criteria: their structure (linear and strip), origin (remnant, along cultivated and regenerated watercourses), or their connectivity. Löw et al. (1995) classify corridors, e.g., by the origin and development of ecosystems, their functionality, biocenosis diversity, connectivity (continuous and discontinuous), and the similarity of connected biocentres (contrast, modal).

More and more authors point to the necessity of maintaining the connectivity of lines within overall landscape management. For example, according to Smith and Hellmund (1993), greenways or wildlife corridors should be seen as elements of the integral strategies of landscape management necessary to maintain the values of a natural environment. In a similar way, Hudgens and Haddad (2003) stress the complexity of the research issues and functionality of corridors; they think viewpoints on biocorridors should be much more panoramic due to their cumulative effects. Linear elements are important landscape elements that enable the movement of species between fragmented habitats (Forman and Baudry, 1984; Saunders and Hobbs, 1991; Opdam et al., 1995; Bennet, 1999). The movement of various plant and animal species along corridors has been monitored by many authors (Hobs, 1992; Mann and Plummer, 1995; Rosenberg et al., 1997). NFWV affect biodiversity since they can be habitats, refuges, corridors or barriers. These functions are essential for many plants and animals that would otherwise not be able to survive in an agricultural landscape (Burel, 1996). In linear biotic formations, predators may prevent pest outbreaks, e.g., invasions of voles (Delattre et al., 1999).

The significance of the width of linear NFWV formations for many groups of invertebrates has been documented in the literature on the subject (Hinsley and Belami, 
2000). Wider vegetation strips promote heterogeneity of microhabitats and diversity of food and other parameters, which facilitate the diversity of invertebrate communities.

Furthermore, as many writers claim, the interconnectivity of NFWV formations is an important attribute affecting their colonization by invertebrates (Baudry, 1988), especially less mobile ones (Cameron et al., 1980). However, identification of the most important attributes of NFWV formations that influence the abundance and diversity of birds is quite complicated. There are numerous studies which assert that the abundance of bird species rises with the increasing size of NFWV lines (with regard to their width and length) (Arnold, 1983; Osborne, 1984; Shalaway, 1985; Green et al., 1994; MacDonald and Johnson, 1995).

Most cases reveal a correlation between the width of NFWV formations and the diversity of bird communities, whereas their height or any other dimension does not seem to be as significant (Hinsley et al., 1999). According to the available data (Hinsley and Belami, 2000), an important factor affecting the structuring of bird communities in NFWV formations is the composition and the height of the forest layer (high NFWV strips with a lot of trees appear to be very attractive to forest bird species).

Another important parameter for all groups of animals is the linkage between NFWV formations and forest habitats (Cameron et al., 1980). The significance of such connectivity was mentioned above. Such a linkage to forest habitats can also encourage the movement of typical forest animal species into the NFWV habitats. On the other hand, the spatial interconnection between multiple linear formations of NFWV allows for communication among individual habitats and provides shelter in the event of migration (e.g., Johnson and Beck, 1988).

We investigated the linear formations of NFWV in an agricultural landscape in the region of Krupina (Slovakia), one of the major wine and fruit-growing regions in Slovakia, which has a typical landscape structure, i.e., vineyards, orchards and lines of trees planted between meadows and arable land.

The verification and supplementation of these actions were carried out on the basis of detailed field research, followed by determining and evaluating the landscapeecological and biotic significance of linear formations of NFWV (acting as biocorridors and interactive elements).

The landscape-ecological and biotic significance of linear formations of NFWV as biocorridors or interacting objects on a local level of TSES were evaluated.

\section{Methods}

Based on the results of our landscape-ecological syntheses, the inventory and mapping of linear formations of NFWV; zoological research; and interpretations of the production, structural, status and ecosozological features of the vegetation; and subsequently on the basis of selected natural hazards, we determined the significance of the linear formations of NFWV, i.e., the conservation of nature, landscape-ecological, biotic (significance of the habitat) and anti-erosion formations. The assessments resulted in specific proposals for the model territory; i.e., TSES elements, proposals for the protection of vegetation, and proposed guidelines for the development of a TSES project.

The focus of the work consisted of the application of theoretical and methodological approaches in the field of landscape ecology, the protection of nature and landscapes, geographic information systems, geobotany, and remote sensing. 
The model territory is located in central Slovakia in the southeastern part of the Štiavnické vrchy Mountains, near the village of Žibritov (latitude 48 $23126.98^{\prime \prime} \mathrm{N}$, longitude 18 59'3.21"E). The highest point of the territory is Buzalkov Hill $(711 \mathrm{~m} \mathrm{a} . \mathrm{s}$. 1.); the lowest point is where the Bebrava River leaves the territory (377 m a. s. 1.); the vertical distance is therefore $334 \mathrm{~m}$.

Most of the model territory is made up of strongly rugged hills, with a smaller part made up of very strongly rugged uplands. On average there are less than 50 summer days per year (Mind'áš and Škvarenina, 2002). The prevailing type of runoff regime is rain-snow, with the highest level of watercourses in March (February to April), the second highest in the late autumn and early winter, and the lowest water levels in September (Šimo and Zat'ko, 2002). The area is dominated by eutric cambisols, typical acid cambisols and luvic cambisols on mineral-rich weathered vulcanites and cambisols on volcanic rocks on steep $12-25^{\circ}$ slopes (Čurlík and Š́ly, 2002). The area is represented by medium heavy soils (clay) and medium heavy- to- lighter soils (sandy loam). The designated area has the character of an agricultural landscape with prevailing permanent grasslands and a varying proportion of NFWV. The area is interesting due to its rich network of linear vegetation elements on borders where regionally rare species of old fruit trees can be found (Fig. 1).

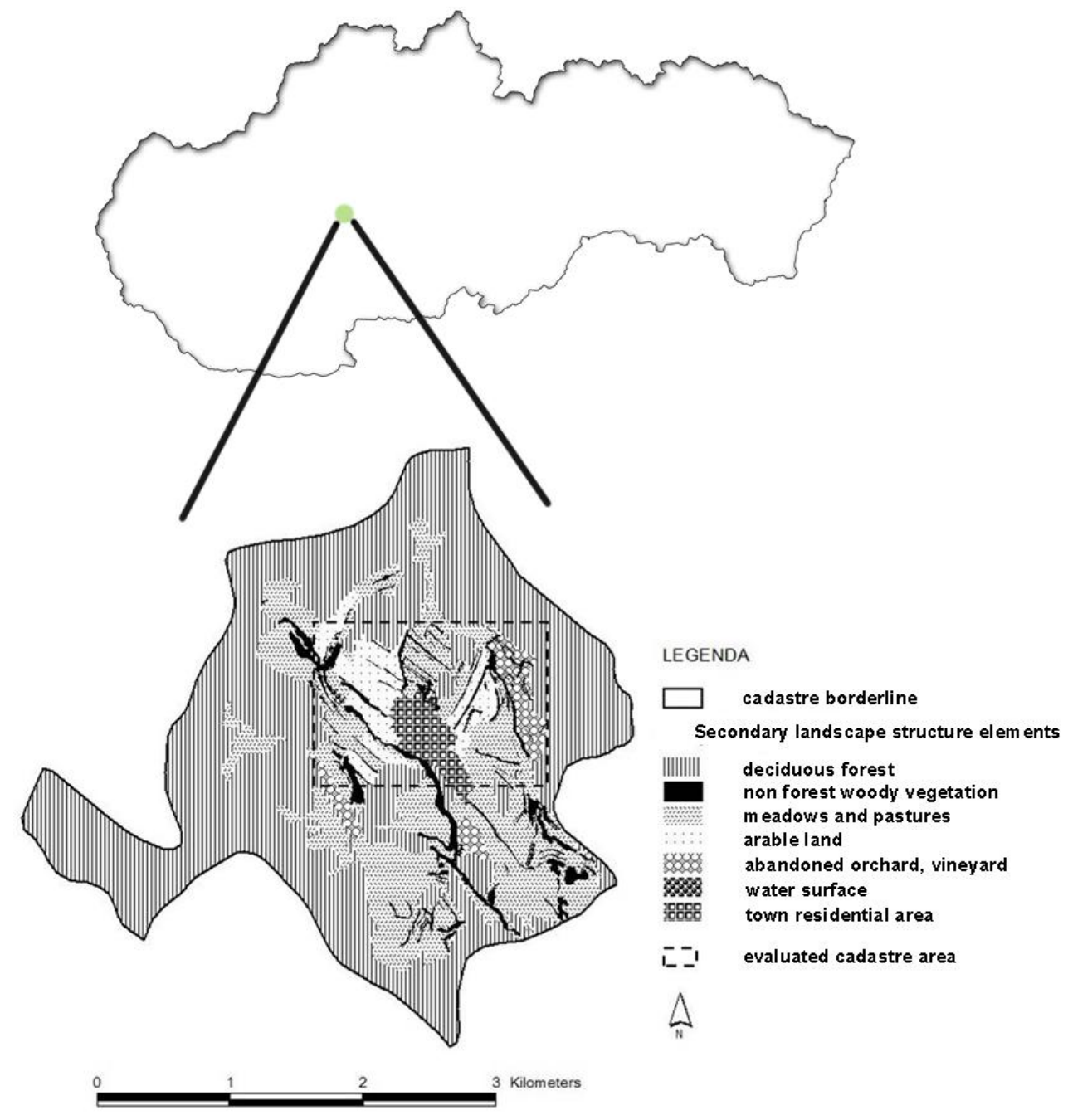

Figure 1. Location of Žibritov study area (AUT) 


\section{Phytocoenological survey of linear formations of NFWV}

During the fieldwork, 38 phytosociological entries at 38 sites and 38 inventories of plant species were made for a total of 76 entries. Selected characteristics (ecological analyses of communities, structural characteristics, status characteristics, ecosozological characteristics, production features and then nature conservation, landscape ecological and anti-erosion significance) were assessed in only 38 linear formations where phytosociological entries were made; the biotic significance (significance of a habitat) was evaluated in 20 linear formations (Fig. 2), particularly in those lines where a zoological survey was conducted. NFWV was mapped within the current landscape structure and by a field inventory of the plant species based on the methods of the Zurich-Montpellier school.

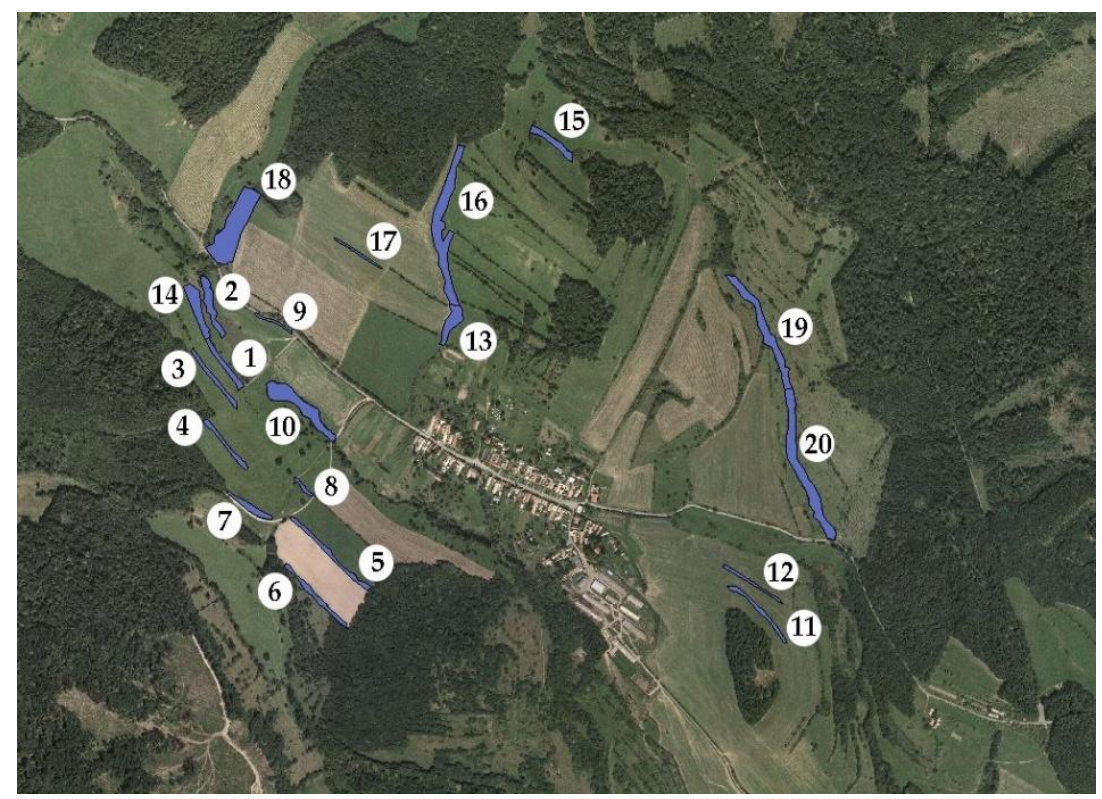

Figure 2. Sites evaluated (AUT)

\section{Zoological survey of the NFWV linear formations}

A basic zoological survey was conducted on 20 randomly selected linear formations of the NFWV of the study area where the following model animal groups were monitored: selected groups of animals living in the upper soil layer or on its surface (Opiliones, Chilopoda, Diplopoda), birds, and small terrestrial mammals. They were chosen in order to characterize the richness of the animal species with different relations to the particular mesohabitats of the NFWV formations. Trapping of epigeic macrofauna was carried out using pitfall traps that were placed in the landscape (Stašiov, 2006). The relation of birds to the NFWV formations was determined based on visual observations, vocal performances, and other signs of residence (e.g., hollowedout tree trunks and old nests). Throughout the fieldwork period we recorded the appearance of larger mammals in the FWV formations observed (visually and through signs of their residence).

Based on the results of both the phytocoenological and the zoological surveys we determined selected structural, state, ecosozological and production characteristics of the vegetation, which have been used for landscape-ecological interpretation. 


\section{Numerical methods and multidimensional analysis of phytocoenological and zoological data}

The impact of the variables of the environment on the composition of the species of the NFWV formations as well as the impact of the NFWV characteristics on the composition of the species of the model of fauna groups were observed using direct gradient analysis (RDA). The CAP and CANOCO software packages were used for the statistical data processing (Ter Braak and Šmilauer, 1998).

\section{Landscape-ecological significance of the vegetation}

The landscape-ecological significance $\left(\mathrm{V}_{\mathrm{ke}}\right)$ was determined on the basis of the following criteria (Jurko, 1990): hemeroby level $(\mathrm{H})$, threat $(\mathrm{O})$, regional rarity $\left(\mathrm{V}_{\mathrm{r}}\right)$, diversity (D), feeding potential $\left(\mathrm{P}_{\mathrm{k}}\right)$, melliferous potential $\left(\mathrm{P}_{\mathrm{m}}\right)$ and stability $\left(\mathrm{S}_{\mathrm{pa}}\right)$. Each criterion was rated on a 10-point scale with increasing values (Table1).

Table 1. Values of selected criteria for determining the landscape-ecological significance of vegetation

\begin{tabular}{|c|c|c|c|c|c|c|c|}
\hline Value & $\begin{array}{c}\text { H - Degree } \\
\text { of } \\
\text { hemeroby } \\
(\%)\end{array}$ & \begin{tabular}{|c|} 
O - Threat to \\
habitats (as per \\
the Slovak system \\
of habitats and \\
their significance)
\end{tabular} & $\begin{array}{l}\mathrm{V}_{\mathrm{r}^{-}} \\
\text {Regional } \\
\text { rarity } \\
\text { (index } \\
\text { value) }\end{array}$ & $\begin{array}{c}\text { D - } \\
\text { Diversity } \\
\text { (Shannon } \\
\text { index } \\
\text { value) }\end{array}$ & $\begin{array}{c}\mathbf{P}_{\mathbf{k}}- \\
\text { Feeding } \\
\text { potential } \\
(\%)\end{array}$ & $\begin{array}{c}\mathbf{P}_{\mathbf{m}}- \\
\text { Melliferous } \\
\text { potential }\end{array}$ & $\begin{array}{c}\text { Degree of } \\
\text { ecological } \\
\text { stability } S_{\text {pa }}\end{array}$ \\
\hline $\begin{array}{c}10 . \\
\text { Extremely } \\
\text { high }\end{array}$ & $\begin{array}{c}\text { Natural } \\
\mathrm{T}<2\end{array}$ & 16 and more & $\begin{array}{l}27 \text { and } \\
\text { more }\end{array}$ & $>4.2$ & $\begin{array}{l}91 \text { and } \\
\text { more }\end{array}$ & $181-200$ & $\begin{array}{c}10 . \\
\text { Extremely } \\
\text { high } \\
\text { stability }\end{array}$ \\
\hline $\begin{array}{l}\text { 9. Very } \\
\text { high }\end{array}$ & $\mathrm{T}: 3-5$ & $12.6-15$ & $23-26$ & $4.0-4.1$ & $81-90$ & $161-180$ & $\begin{array}{l}\text { 9. Very } \\
\text { high } \\
\text { stability }\end{array}$ \\
\hline $\begin{array}{c}\text { 8. High to } \\
\text { very high }\end{array}$ & $\begin{array}{c}\text { Almost } \\
\text { natural } \\
\text { T: } 6-10 \text {, } \\
\mathrm{N}<3\end{array}$ & $10.1-12.5$ & $20-22$ & $3.8-3.9$ & $71-80$ & $141-160$ & $\begin{array}{l}8 . \text { High to } \\
\text { very high } \\
\text { stability }\end{array}$ \\
\hline 7. High & $\begin{array}{c}\mathrm{T}: 11-15, \\
\mathrm{~N}<7\end{array}$ & $7.6-10 \%$ & $17-19$ & $3.6-3.7$ & $61-70$ & $121-140$ & $\begin{array}{l}\text { 7. High } \\
\text { stability }\end{array}$ \\
\hline $\begin{array}{l}\text { 6. Medium } \\
\text { to high }\end{array}$ & $\begin{array}{c}\text { Semi- } \\
\text { natural } \\
\text { T: } 16-20, \mathrm{~N}: \\
8-12\end{array}$ & $6.1-7.5$ & $14-16$ & $3.4-3.5$ & $51-60$ & $101-120$ & $\begin{array}{l}\text { 6. Medium } \\
\text { to high } \\
\text { stability }\end{array}$ \\
\hline 5. Medium & $\begin{array}{c}\mathrm{T}: 21-25, \\
\mathrm{~N}<13-18 \\
\end{array}$ & $4.6-6$ & $11-13$ & $3.2-3.3$ & $41-50$ & $81-100$ & $\begin{array}{c}\begin{array}{c}\text { 5. Medium } \\
\text { stability }\end{array} \\
\end{array}$ \\
\hline $\begin{array}{l}\text { 4. Low to } \\
\text { medium }\end{array}$ & $\begin{array}{c}\text { Cultivated } \\
\mathrm{T}: 26-35, \mathrm{~N}: \\
19-22\end{array}$ & $3.1-4.5$ & $8-10$ & $3.0-3.1$ & $31-40$ & $61-80$ & $\begin{array}{l}\text { 4. Low to } \\
\text { medium } \\
\text { stability }\end{array}$ \\
\hline 3. Low & $\begin{array}{c}\text { Artificial } \\
\mathrm{T}>36, \\
\mathrm{~N}: 23-35\end{array}$ & $1.6-3$ & $5-7$ & $2.8-2.9$ & $21-30$ & $41-60$ & $\begin{array}{l}\text { 3. Low } \\
\text { stability }\end{array}$ \\
\hline $\begin{array}{l}\text { 2. Very } \\
\text { low }\end{array}$ & $N>36$ & $0-1.5$ & $2-4$ & $2.6-2.7$ & $11-20$ & $21-40$ & $\begin{array}{c}\text { 2. Very low } \\
\text { stability }\end{array}$ \\
\hline $\begin{array}{c}1 . \\
\begin{array}{c}\text { Extremely } \\
\text { low }\end{array} \\
\end{array}$ & Devastated & 0 & 1 or less & $<2.6$ & $0-10$ & $0-20$ & $\begin{array}{c}\text { Extremely } \\
\text { low stability }\end{array}$ \\
\hline
\end{tabular}


The final value of the landscape-ecological significance was calculated using Equation 1:

$$
v_{k e}=\frac{\left(H+O+V_{r}+D+P_{k}+P_{m}\right) * S_{p a}}{100}
$$

The final value was classified on an 8-point scale: 1 . extremely low $(<0.4), 2$. very low (0.4-1), 3. low (1-2), 4. low to medium 4 (2-2.5), 5. medium (2.5-3), 6. high (3-3.5), 7. very high (3.5-4), 8. extremely high $(>4)$.

The biotic significance (the significance of the habitats) $V_{\text {bio }}$ was assessed in the first 20 linear formations (as the zoological survey was carried out only at the first 20 sites), according to the criteria defined by the results from the field survey and the modified methodology by Sláviková (1987). The following criteria were involved: the value of the Shannon diversity index of plant $\left(\mathrm{H}_{\mathrm{D} 1}\right)$ and animal $\left(\mathrm{H}_{\mathrm{D} 2}\right)$ communities, the minimum width of a formation, adjacent habitats, line connectivity with other formations, and stratification. Values of 1-3 were attached to the criteria (Table 2).

The final value of the biotic significance of the assessed lines was the sum of the points for particular characteristics; it was classified on a 3-point scale $V_{\text {bio }}$ : 1 - high (15-16p), 2 - medium (13-14p), and 3 - low (10-12p).

Table 2. Values of selected criteria for determining the biotic significance of vegetation

\begin{tabular}{c|c|c|c|c|c|c}
\hline Value & $\begin{array}{c}\mathbf{H}_{\text {D1 }} \text { - Diversity } \\
\text { (value of } \\
\text { Shannon index } \\
\text { of plant } \\
\text { communities) }\end{array}$ & $\begin{array}{c}\mathbf{H}_{\mathbf{D} \text { - Diversity }} \text { (value of } \\
\text { Shannon index } \\
\text { of animal } \\
\text { communities) }\end{array}$ & $\begin{array}{c}\text { Min. width } \\
\mathbf{( m )}\end{array}$ & $\begin{array}{c}\text { Surrounding } \\
\text { habitats }\end{array}$ & Connectivity & Stratification \\
\hline $\mathbf{3}$ - High & $3.9-4.2$ & $2.5-2.2$ & 15 and more & $\begin{array}{c}\text { Meadow } \\
\text { vegetation }\end{array}$ & Water habitats & 3 layers \\
\hline $\mathbf{2}$ - Medium & $3.5-3.8$ & $2.1-1.8$ & $10-14$ & Arable land & $\begin{array}{c}\text { Habitats } \\
\text { connected with } \\
\text { a forest or } \\
\text { other NFWV }\end{array}$ & 2 layers \\
\hline $\mathbf{1}$ - Low & $3.1-3.4$ & $1.7-1.4$ & 9 and less & Roads & $\begin{array}{c}\text { Isolated } \\
\text { habitats } \\
\text { without water }\end{array}$ & 1 layer \\
\hline
\end{tabular}

\section{TSES elements and nature and landscape protection}

After the assessment of the qualitative and quantitative characteristics of the evaluated lines, the formations were proposed as TSES elements; i.e., as part of local biocorridors or interactive elements, or they were proposed for nature protection.

\section{Results}

\section{Evaluation of the NFWV linear formations based on the phytocoenological survey}

Based on the physiognomy, composition of species, and ecotopes of the following types of habitats, linear formations of NFWV were specified in the territory observed (Table 3): 
Table 3. The habitat types

\begin{tabular}{c|c}
\hline Code & Habitats (site) \\
\hline V1-V4 & $\begin{array}{c}\text { Hygrophilous habitats of submontane alder floodplain forests (Alnion incanae) } \\
\text { Pawlowski et al. 1928, Alnenion glutinoso-incanae Oberd. 1953: Aegopodio-Alnetum)- } \\
\text { riparian vegetation (sites No. 2, 10, 19, 20) }\end{array}$ \\
\hline L1-L4 & $\begin{array}{c}\text { Fragments of Carpathian oak-hornbeam forests (zv. Carpinion Issler 1931, Carici } \\
\text { pilosae-Carpinion betuli J. et M. Michalko: Quercopetreae-Carpinetum Soó et Pócs } \\
\text { 1957) - fragments of forest vegetation (Site Nos.13, 14, 16, 18) }\end{array}$ \\
\hline KL & $\begin{array}{c}\text { Blackthorn hazel shrubbery called Berberidion Br.-Bl. 1950, Populo-Coryletum Br.-B1. } \\
\text { 1950) (Site No.15) }\end{array}$ \\
\hline Ra1-Ra8, Rb1 & $\begin{array}{c}\text { Avenues (bocages) - linear woody, mostly three-layer formations of small dimensions, } \\
\text { surrounded by grasslands or arable land in balks where the tree layer is represented by } \\
\text { human-planted species (Pyrus domestica, Malus domestica, Juglans regia, Prunus } \\
\text { domestica); these are thus anthropogenically determined biocorridors (Ra Site Nos. 1, 3, } \\
\text { 4, 5, 6, 8, 11, 12). They occur mostly in meadows, but also on arable land along roads. } \\
\text { They adjoin forest stands, other formations of NFWV, or are completely isolated. } \\
\text { Avenues with the occurrence of synanthropic species and avenues with intergrowing } \\
\text { species of surrounding forest stands and with the occurrence of synanthropic species are } \\
\text { in Rb site No. 17 }\end{array}$ \\
\hline C1, C2 & $\begin{array}{c}\text { Continuous accompanying tree-lines along a third class road running across the centre } \\
\text { of the study area or along an unpaved field road. This concerns Site Nos. 7 and 9 }\end{array}$ \\
\hline
\end{tabular}

\section{Evaluation of habitats based on ecological and location features}

The environmental characteristics and quantitative features of the NFWV lines assessed are documented in Tables 4 and 5.

Table 4. Environmental characteristics and quantitative features of the NFWV lines assessed

\begin{tabular}{|c|c|c|c|c|c|c|c|c|c|c|c|c|c|c|c|c|c|c|c|c|}
\hline Variable/Site & 1 & 2 & 3 & 4 & 5 & 6 & 7 & 8 & 9 & 10 & 11 & 12 & 13 & 14 & 15 & 16 & 17 & 18 & 19 & 20 \\
\hline Minimum width (m) & 10 & 9 & 8 & 7 & 7 & 6 & 6 & 7 & 4 & 15 & 7 & 5 & 11 & 14 & 15 & 15 & 5 & 47 & 14 & 15 \\
\hline Maximum width (m) & 18 & 21 & 11 & 13 & 14 & 19 & 16 & 10 & 7 & 50 & 13 & 9 & 35 & 32 & 22 & 41 & 7 & 70 & 33 & 30 \\
\hline Area $\left(\mathbf{m}^{2}\right)$ & 531 & 477 & 531 & 518 & 531 & 510 & 528 & 509 & 508 & 480 & 480 & 480 & 540 & 531 & 530 & 550 & 540 & 526 & 530 & 530 \\
\hline Length (m) & 147 & 161 & 174 & 159 & 258 & 215 & 127 & 62 & 105 & 217 & 201 & 178 & 104 & 140 & 122 & 400 & 139 & 20 & 323 & 390 \\
\hline Geological substrate & 4 & 4 & 1 & 1 & 1,3 & 1,3 & 3 & 3 & 1 & 4 & 1 & 1 & 1 & 3 & 2 & 1,2 & 1,5 & 1 & 3 & 3,4 \\
\hline Soil type & 1 & 2 & 1 & 1 & 1 & 1 & 1 & 1 & 1 & 2 & 1 & 1 & 1 & 1 & 1 & 1 & 1 & 1 & 1 & 1 \\
\hline Soil depth & 2 & 5 & 2 & 2 & 2 & 2 & 2 & 4 & 4 & 5 & 2 & 2 & 2 & 2 & 5 & 2 & 2 & 1 & 5 & 5 \\
\hline Soil group & 1 & 2 & 1 & 1 & 1 & 1 & 1 & 1 & 1 & 2 & 1 & 1 & 1 & 1 & 2 & 1 & 1 & 1 & 2 & 2 \\
\hline Slope inclination & 5 & 2 & 5 & 4 & 4 & 4 & 4 & 4 & 3 & 2 & 4 & 4 & 4 & 4 & 4 & 4 & 4 & 4 & 4 & 4 \\
\hline Altitude (m a. s. l.) & 531 & 477 & 531 & 518 & 531 & 510 & 528 & 509 & 508 & 480 & 480 & 480 & 540 & 531 & 530 & 550 & 540 & 526 & 530 & 530 \\
\hline Landforms & 6 & 8 & 6 & 6 & 2 & 6 & 2 & 6 & 6 & 8 & 6 & 6 & 6 & 6 & 4 & 3 & 6 & 3 & 4 & 4 \\
\hline Orientation to cardinal points & 2 & 4 & 2 & 2 & 2 & 2 & 4 & 2 & 5 & 4 & 2 & 2 & 6 & 3 & 4 & 5 & 6 & 7 & 4 & 4 \\
\hline Surrounding biotopes & 1 & 1 & 1 & 1 & 2 & 3 & 5 & 1 & 5 & 4 & 1 & 1 & 2 & 1 & 1 & 2 & 6 & 5 & 1 & 1 \\
\hline Connectivity & 2 & 2 & 3 & 1 & 1 & 1 & 1 & 2 & 2 & 3 & 3 & 3 & 2 & 2 & 3 & 1 & 3 & 1 & 2 & 2 \\
\hline Cover of layer $\mathbf{E}_{3}(\%)$ & 40 & 100 & 50 & 80 & 60 & 65 & 65 & 60 & 70 & 100 & 50 & 40 & 60 & 70 & 60 & 60 & 35 & 80 & 100 & 100 \\
\hline Cover of layer $\mathbf{E}_{2}(\%)$ & 80 & 75 & 80 & 50 & 75 & 90 & 85 & 50 & 70 & 50 & 70 & 80 & 90 & 90 & 85 & 90 & 95 & 65 & 35 & 25 \\
\hline Crown cover $\mathbf{E}_{3}$ & 5 & 1 & 4 & 4 & 3 & 3 & 3 & 4 & 3 & 1 & 3 & 5 & 3 & 2 & 3 & 3 & 5 & 1 & 1 & 1 \\
\hline Crown cover $\mathbf{E}_{2}$ & 4 & 2 & 2 & 3 & 2 & 3 & 3 & 2 & 1 & 3 & 3 & 3 & 1 & 1 & 1 & 2 & 2 & 4 & 5 & 5 \\
\hline
\end{tabular}


Table 5. Explanations for Table 4

\begin{tabular}{|c|c|}
\hline Code & Environmental characteristics \\
\hline \multicolumn{2}{|r|}{ Geological substrate } \\
\hline 1 & Unspecified pyroxene andesite \\
\hline 2 & Pyroxene andesite (augite-hypersthene) \\
\hline 3 & Deluvial sediments - polygenetic slope loam \\
\hline 4 & Fluvial floodplain sediments: mostly loam and sandy loam \\
\hline 5 & Deluvial-fluvial hillwash loam, sandy loam \\
\hline \multicolumn{2}{|r|}{ Soil type } \\
\hline 1 & Cambisol \\
\hline 2 & Luvisol \\
\hline \multicolumn{2}{|r|}{ Soil depth (cm) } \\
\hline 1 & Very shallow (15) \\
\hline 2 & Shallow (15-30) \\
\hline 3 & Moderately deep (30-60) \\
\hline 4 & Deep (60-100) \\
\hline 5 & Very deep $(100-200)$ \\
\hline \multicolumn{2}{|r|}{ Soil group (granularity) } \\
\hline 1 & Silty - loam \\
\hline 2 & Silty - clayey - loam \\
\hline \multicolumn{2}{|r|}{ Slope orientation $\left({ }^{\circ}\right)$} \\
\hline 2 & $1-3$ \\
\hline 3 & $3-7$ \\
\hline 4 & $7-12$ \\
\hline 5 & $12-17$ \\
\hline \multicolumn{2}{|r|}{ Landform } \\
\hline 2 & Plateau \\
\hline 3 & Dome-shaped peak \\
\hline 4 & Ridge \\
\hline 6 & Transport slope \\
\hline 8 & Slope plateau \\
\hline \multicolumn{2}{|r|}{ Orientation to cardinal points } \\
\hline 2 & $\mathrm{NE}$ \\
\hline 3 & E \\
\hline 4 & SE \\
\hline 5 & $\mathrm{~S}$ \\
\hline 6 & SW \\
\hline 7 & W \\
\hline \multicolumn{2}{|r|}{ Surrounding biotopes } \\
\hline 1 & Meadow \\
\hline 2 & Meadow and large block fields \\
\hline 3 & Forest and large block fields \\
\hline 4 & Meadow and small-scale and narrow-strip fields \\
\hline 5 & Meadow and road \\
\hline 6 & Large block fields \\
\hline
\end{tabular}




\begin{tabular}{|c|c|}
\hline \multicolumn{2}{|r|}{ Connectivity } \\
\hline 1 & To forest \\
\hline 2 & To other NFWV types \\
\hline 3 & Isolated \\
\hline \multicolumn{2}{|r|}{ Crown cover of $\mathbf{E}_{3}, \mathbf{E}_{2}$} \\
\hline 1 & $\begin{array}{l}\text { Dense to continuous - crowns of neighbouring trees (shrubs) overlap and touch, they } \\
\text { affect each other }\end{array}$ \\
\hline 2 & $\begin{array}{c}\text { Loose - tree (shrubs) crowns touch; or there is a gap of an average crown size of the } \\
\text { wood species typical of a given formation }\end{array}$ \\
\hline 3 & $\begin{array}{l}\text { Interrupted to gapped - a gap of an average crown size of the wood species typical of a } \\
\text { given formation, to a gap of } 5 \mathrm{~m}\end{array}$ \\
\hline 4 & $\%$ of the interlocking parts is less than or equal to the gapped parts of a formation \\
\hline 5 & Sparse trees and shrubs \\
\hline
\end{tabular}

No neophytes were present in the linear formations evaluated or their surroundings. The occurrence of therophytes was also relatively low, i.e., about 3.56\%. The final assessment states that almost all the habitats mapped showed near-natural hemeroby levels; they recorded average values of 9, 8 in the evaluation of landscape-ecological significance. Protected, endangered or rare species were not observed. According to aspects of regional rarity, common taxa represented the largest group (abundant). Uncommon taxa are species scattered in the study area and are habitat-bound (e.g., Sorbus torminalis, Quercus cerris, Pyrus pyraster, Bryonia dioica, Poa palustris, etc.) or species in less well- known sites and less widespread species. Rare species include domesticated wood species, which in the area of Žibritov have their northernmost sites (Malus domestica, Pyrus domestica, Mespilus germanica, Cerasus sp., etc.) and are evaluated in terms of their historically determined occurrence; then there are species that occur sporadically in the southeastern and southern parts of the Štiavnické vrchy mountains, in the oak-hornbeam forests (e.g., Carduus nutans).

The final values of regional rarity ranged from 3.4 to 26.0. Formations with the highest values were avenues (Site Nos. 6, 11 and 12). On the other hand, low or very low values $(3.4,8)$ were assigned to avenues with synanthropic species, blackthorn shrubbery with synanthropic species and fragments of forest stands (e.g., Site Nos. 13 and 16). The other sites showed medium- to- high degrees of regional rarity.

Species with low feeding potential represent the largest group in the habitats evaluated. These include hygrophilous, synanthropic and forest species such as Artemisia vulgaris, Aruncus sylvestris, Barbarea vulgaris, Centaurea phrygia, Juncus conglomeratus, etc. Species with medium and excellent feeding potential had the lowest representation (Festuca pratensis, Lolium perenne, Poa palustris, Trifolium repens, Poa pratensis etc.). Five percent (5\%) of the species were inappropriate or even very harmful for use as food (Colchicum autumnale, Euphorbia cyparissias, Pteridiumaqiulinum, etc.).

Very low levels of feeding potential (29-30) were observed in fragments of some forest ecosystems (Site Nos. 14, 16 and 18) and narrow tree-lines occurring mostly along roads (e.g., Site Nos. 8 and 14). Avenues or avenues with intergrowing species of surrounding forest stands reached an average value (46-48), which was the highest among all the sites evaluated (e.g., Site Nos. 1, 6, 17). The other sites have low-tomedium levels of feeding potential. 
An overall assessment of the melliferous potential shows that the sites evaluated have great potential, i.e., they have a high percentage of species with reserves of nectar and pollen. The highest melliferous potential with very high values, i.e., above $150 \%$, was observed at Site Nos. 1 and 7. These are avenues with intergrowing forest species. Medium-to-high values of melliferous potential (106-110\%) were assigned to linear fragments of forest stands (Site Nos. 13 and 18) as well as some alleys (e.g., Site No. 17). The other sites assessed showed high or high-to-very high values of melliferous potential.

Each type of habitat was assigned the following degree of ecological stability (Table 6).

Table 6. The ecological stability of the types of habitat

\begin{tabular}{c|c}
\hline Code & Degree of ecological stability (Site) \\
\hline $\mathbf{1 0}$ & Extremely high stability - original habitats without human intervention, value was not assigned \\
\hline $\mathbf{9}$ & Very high stability - submontane alder floodplain forests (Site Nos. 2, 10, 19 and 20) \\
\hline $\mathbf{8}$ & High-to-very-high stability - fragments of oak-hornbeam forests (Site Nos. 13, 14, 16, 18) \\
\hline $\mathbf{7}$ & High stability - blackthorn hazel shrubbery (Site No. 15) \\
\hline $\mathbf{6}$ & $\begin{array}{c}\text { Medium-to-high stability - avenues with intergrowing species of surrounding forest stands (Site } \\
\text { Nos. 1, 3, 4, 5, 6, 7, 8, 11 and 12) }\end{array}$ \\
\hline $\mathbf{5}$ & Medium stability - avenues along roads (Site No. 9) \\
\hline $\mathbf{4}$ & $\begin{array}{c}\text { Low-to-medium stability - avenues with intergrowing species of surrounding forest stands and } \\
\text { with synanthropic species (Site No. 17) }\end{array}$ \\
\hline
\end{tabular}

The values of the Shannon diversity index H ranged from 3.2 to 4.1. A lower degree of diversity was observed in riparian vegetation along the left-bank tributary of the Bebrava River (Sites 19 and 20) with formations made of grazed permanent grasslands, avenues with synanthropic species in balks, on arable land (Site No. 17), and fragments of forest stands (Site Nos. 13, 14 and 18).

Conversely, the highest degree of diversity was found to be in avenues with intergrowing forest species (e.g., Site Nos. 1, 3, 4) that occurred in the north-western part of the study area, mostly on twice-mown meadows (lowland hay meadows, Arrhenatherion elatioris, Koch, 1926). The other sites showed medium to medium-high biodiversity.

The defined criteria utilised to evaluate the importance of NFWV in our research is documented in Table 7.

\section{Evaluation of the impact of environmental variables on types of vegetation}

The variables tested (15 variables) amounted to $39.9 \%$ of the total variability in the specific data. The variables with a demonstrable impact were types of soil, minimum width, altitude, orientation to the cardinal points, geological substrate, and cover of $\mathrm{E}_{2}$ and $\mathrm{E}_{3}$ layers (Fig. 3).

For other variables (the area, length, maximum width, type of soil, depth of soil, land forms, skeletality, connectivity, slope inclination), the probability of error was quite high. The variable soil type has the most variability in this case, i.e., 11.3\%. Riparian vegetation (Site Nos. 2, 10, 19 and 20) and blackthorn hazel shrubbery (Site No. 15) had a positive correlation with the soil texture. Only these sites were covered with silty- 
clayey-loam soil; the other sites were covered with silty-loam soil. In the linesmentioned wet habitats most commonly occurred.

Table 7. Defined criteria utilised in the evaluation of the landscape ecological and biotic importance of the NFWV

\begin{tabular}{c|c|c|c|c|c|c|c|c|c|c|c|c|c|c|c|c|c|c|c|c}
\hline Criteria/site & $\mathbf{1}$ & $\mathbf{2}$ & $\mathbf{3}$ & $\mathbf{4}$ & $\mathbf{5}$ & $\mathbf{6}$ & $\mathbf{7}$ & $\mathbf{8}$ & $\mathbf{9}$ & $\mathbf{1 0}$ & $\mathbf{1 1}$ & $\mathbf{1 2}$ & $\mathbf{1 3}$ & $\mathbf{1 4}$ & $\mathbf{1 5}$ & $\mathbf{1 6}$ & $\mathbf{1 7}$ & $\mathbf{1 8}$ & $\mathbf{1 9}$ & $\mathbf{2 0}$ \\
\hline $\begin{array}{c}\text { H (\% presence of } \\
\text { terophytes) }\end{array}$ & 4.1 & 10 & 1.8 & 3.1 & 0.7 & 1.2 & 3 & 4.5 & 7.8 & 7.9 & 7 & 5.6 & 0.8 & 1.6 & 1.1 & 4.1 & 1.8 & 1.7 & 1.3 & 2 \\
$\mathbf{V}_{\mathbf{r}}$ & 13 & 20 & 15 & 20 & 22 & 26 & 22 & 19 & 23 & 22 & 26 & 26 & 3.4 & 11 & 12 & 8 & 25 & 13 & 15 & 9.1 \\
$\mathbf{H}_{\mathbf{D} 1}$ & 4 & 3.7 & 4.1 & 4 & 4 & 3.8 & 3.8 & 3.8 & 3.6 & 3.5 & 3.7 & 3.4 & 3.3 & 3.3 & 3.9 & 3.3 & 3.3 & 3.3 & 3.2 & 3.4 \\
$\mathbf{H}_{\mathbf{D} 2}$ & 2.5 & 2.3 & 2.4 & 2.5 & 2.2 & 2.2 & 2.2 & 1.5 & 2.2 & 2.1 & 2.3 & 2.2 & 2.3 & 2.2 & 2.1 & 2.1 & 2 & 2.1 & 2.1 & 1.7 \\
$\mathbf{P}_{\mathbf{k}}$ & 48 & 28 & 41 & 45 & 36 & 48 & 35 & 30 & 33 & 37 & 37 & 40 & 34 & 29 & 40 & 30 & 46 & 20 & 29 & 27 \\
$\mathbf{P}_{\mathbf{m}}$ & 167 & 124 & 147 & 130 & 143 & 132 & 156 & 123 & 144 & 140 & 128 & 128 & 110 & 128 & 132 & 153 & 106 & 107 & 149 & 140 \\
$\mathbf{S}_{\mathbf{p a}}$ & 6 & 9 & 6 & 6 & 6 & 6 & 5 & 6 & 5 & 9 & 6 & 6 & 8 & 8 & 7 & 8 & 4 & 8 & 9 & 9 \\
\hline
\end{tabular}

Explanations: $\mathrm{H}-$ hemeroby gradient, $\mathrm{V}_{\mathrm{r}}-$ regional rarity, $\mathrm{H}_{\mathrm{D} 1}-$ Shannon index of diversity of vegetation communities, $\mathrm{H}_{\mathrm{D} 2}-$ Shannon index of diversity of animal communities, $\mathrm{P}_{\mathrm{k}}$ - feeding potential, $\mathrm{P}_{\mathrm{m}}-$ melliferous potential, $\mathrm{S}_{\mathrm{pa}}-$ stability status

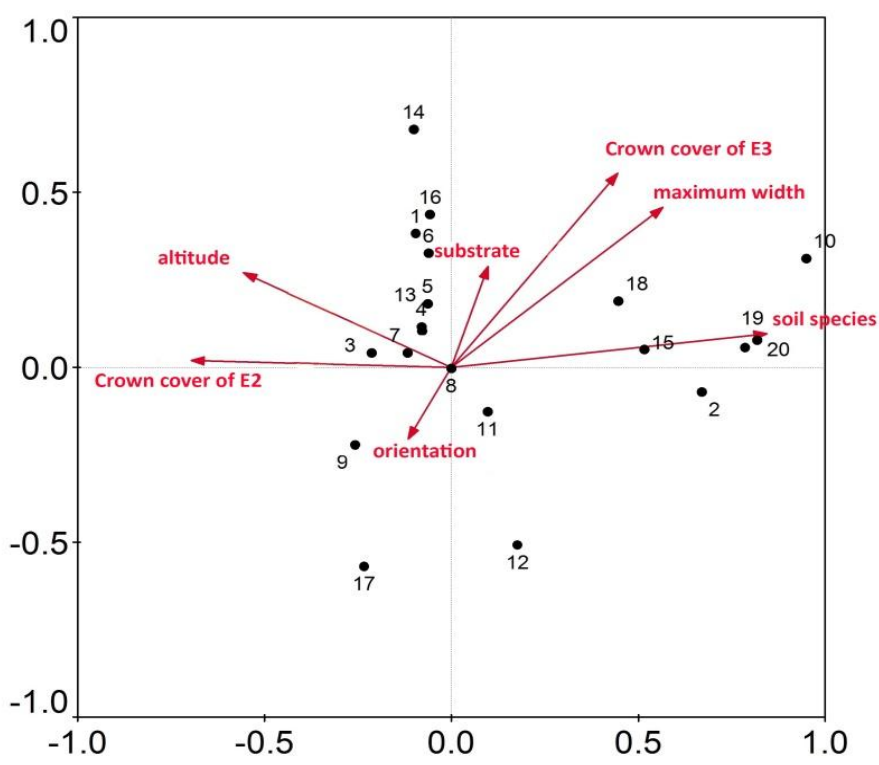

Figure 3. RDA ordination diagram (ordination of phytocoenological entries and environmental characteristics (AUT)

The cover of the $\mathrm{E}_{3}$ layer represented $9.6 \%$ of the total variability of the data and positively correlated with Site No. 21. It was a fragment of oak-hornbeam forests, with an $\mathrm{E}_{3}$ cover layer of $100 \%$ and dense- to-continuous crown cover. With an increasing cover of the $E_{3}$ layer, the cover of species in layers $E_{2}$ and $E_{1}$ decreases.

Another significant variable was the minimum width, which represented $5.2 \%$ of the total variability. Site No. 18, which was a fragment of oak-hornbeam forests and a strip with the greatest width of $47 \mathrm{~m}$, had a positive correlation with a minimum width. The abundance of species in each layer increases with the increasing width of the lines evaluated. The other significant variables represented less than $5 \%$ of the total variability of the data. 


\section{Evaluation of the linear formations of NFWV based on the zoological survey}

The zoological survey of the macroedaphone in twenty formations of NFWV found 15 taxa of Opiliones, 15 taxa of Millipedes, and 19 taxa of Centipedes). From afaunistic point of view, the most important are the finds of Dicranolas mascabrum and Lamyces fulvicornis, which are rare species, and Egeanus convexus and Zacheus crista, which are on the red list of rare and endangered species.

When evaluating the impact of environmental variables on the structure of communities of the selected groups of macroedaphone, the only significant variable was the "minimum width" structural feature (Fig.4).

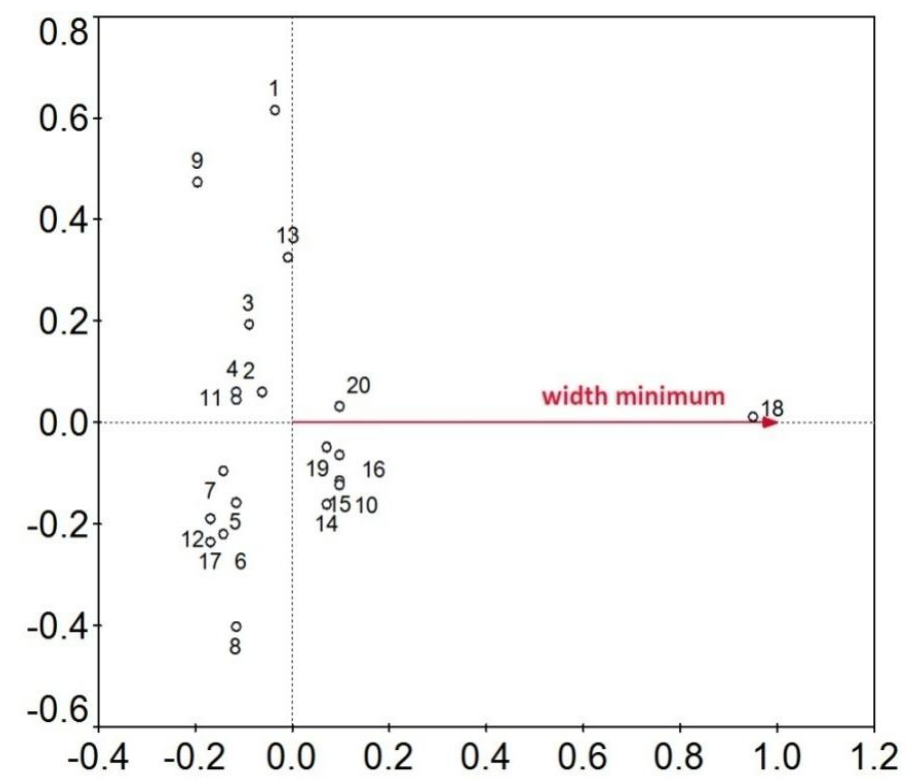

Figure 4. Evaluation of the impact of environmental variables on the structure of communities of the selected groups of macroedaphone (AUT)

The most favourable formations in the study area appear to be habitats with the greatest width.

We determined that there are 37 bird species in the NFWV formations observed. The area was dominated by species typical of an open landscape with the occurrence of NFWV and species typical of forest habitats or synanthropic bird species.

Based on the data on the presence of species, a classification of the habitats observed was made in terms of their significance and suitability as representatives of avifauna. Three main groups of habitats (categories) can be defined in the study area:

- Habitats of NFWV with water: in terms of birds, they are the most important and most valuable biocorridors. The highest number of bird species live here and in the greatest abundance (Site Nos. 2, 10, 19, 20).

- Habitats of NFWV that adjoin forests (or link forest stands) represent an intermediate stage between 1 and 3 (Site Nos. 4, 5, 6, 7, 13, 16 and 18).

- Habitats without water that do not adjoin forests: the lowest number of bird species live here and are in the lowest abundance as well (Sites Nos. 1, 3, 8, 11, 12, 14 and 17). 
In the evaluation of the significance of the characteristics of the NFWV formations studied, the following significant environmental variables for bird communities were determined: connectivity (a link with another NFWV formation or forest habitat), the nature of the surrounding habitats, the $\mathrm{E}_{2}$ cover layer, and orientation to the cardinal points (Fig. 5).

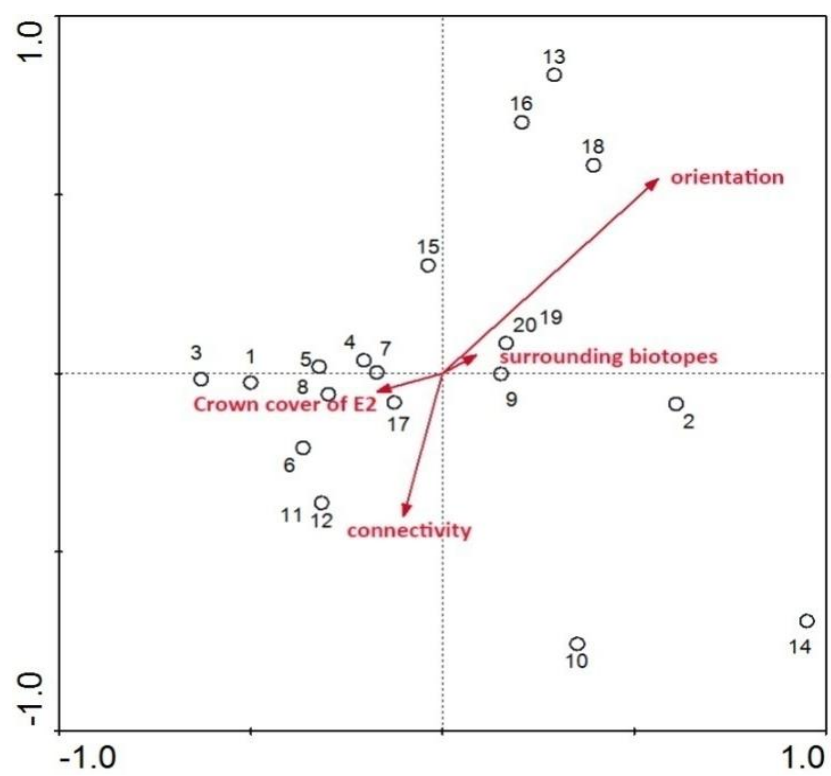

Figure 5. Evaluation of the significance of the environmental characteristics and features of the NFWV formations for bird communities

The formations observed have six (6) species of small mammals that are typical of submontane and alpine communities of shrubs and forests. The overall abundance of this group of animals was very low; therefore, the data on their occurrence were not subject to further analysis.

\section{Evaluation of the landscape-ecological and biotic significance of the vegetation}

An overall assessment of the landscape-ecological significance of the vegetation shows that most of the sites evaluated recorded low- to- medium values ranging from 2.0 to 2.5 . These are mainly avenues, avenues with intergrowing species of the surrounding forest stands that occur in meadows with a high regional rarity index, a high diversity index, high values of melliferous potential and a moderate level of feeding potential. There are also fragments of forest stands and blackthorn hazel shrubbery with a high degree of hemeroby and stability.

The riparian vegetation had the highest $\mathrm{V}_{\mathrm{ke}}$ values, ranging from 2.61 to 3.06 (Site Nos. 2, 10, 19 and 20). This concerns natural riparian vegetation, i.e., alder floodplain forests with a very high degree of stability, hemeroby and diversity, high values of melliferous potential and medium values of feeding potential.

Conversely, Site Nos. 7, 8, 9 and 17 had low-to-very low values of landscapeecological significance (1.36-1.98). These are avenues and blackthorn shrubbery that mostly grow on arable land with an increased occurrence of synanthropic species, low diversity and stability. 
The assessment of the biotic significance of the vegetation shows that the highest values of the significance of habitats $(15-16 \mathrm{~b})$ were assigned to riparian vegetation (Site Nos. 2, 10 and 19), tree lines occurring in the vicinity of water areas that adjoin forests (Site Nos. 1 and 4) and blackthorn hazel shrubbery (Site No. 15). Site Nos. 7 , $8,9,12$ and 17 had the lowest values (10-12b). These are avenues along roads that are completely isolated or occurring in meadows and on arable land. The other sites, which were mostly avenues adjoining forest stands or another NFWV formation, belong to moderately significant habitats (13-14b), i.e., Site Nos. 3, 5, 6, 11, 13, 14, 16, 18 and 20. Figure 6 shows the values of the landscape-ecological and biotic significance of each site.

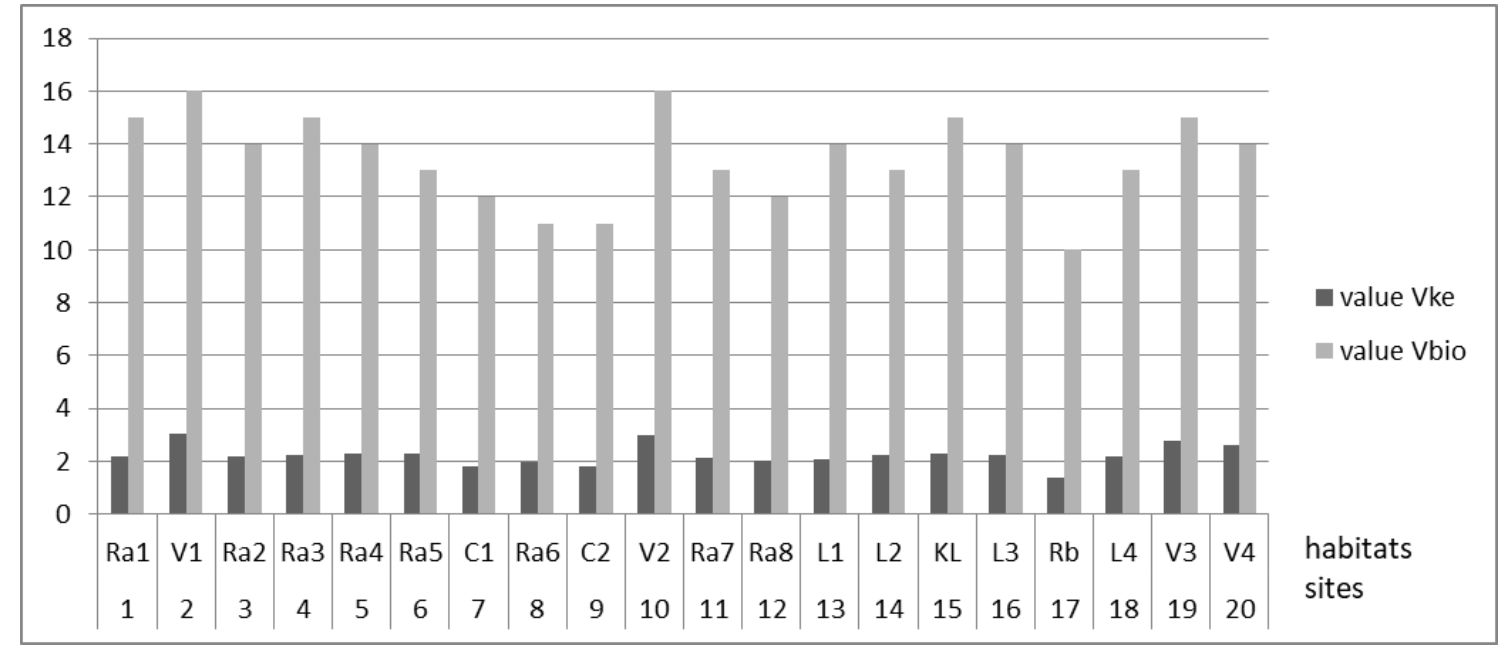

Figure 6. Landscape-ecological and biotic significance of the assessed sites (AUT)

The overall assessment of the landscape-ecological and biotic (significance of the habitat) importance of the linear formations examined reveals that the most valuable habitats include riparian vegetation - sub-mountain alder floodplain forests (Site Nos. 2, 10, 19 and 20), which function as a part of local biocorridors since they meet the criteria (quantitative and qualitative) to be designated as such. These valuable lines of extraordinary biodiversity have medium-to-high landscape-ecological significance, so the significance values are lower from the point of view of nature protection (the evaluations did not consider protection of habitats, only the protection of individual species). They are habitats with an extremely high degree of ecological stability, hemeroby, diversity, and feeding and melliferous potential, and with a relatively low number of regionally rare species. From a zoological perspective, they represent the most valuable habitats for members of avifauna (most abundantly inhabited by bird species) and higher vertebrates. These habitats are also important from the point of view of the group of macroedaphones.

The fragments of oak-hornbeam Carpathian forests (Site Nos. 13, 16 and 18) are essential in terms of their significance for erosion control and exhibited a medium-tolow value of landscape-ecological significance, with a low-to-very low value of significance for nature protection (again, the assessment did not take the protection of habitats into account); in terms of their biotic significance (significance of a habitat), they are also considered valuable. They occur on slopes on arable land, where the 
erosive rate of soil removal (according to the erosion models) exceeds the limit values for a certain depth of soil. They are also valuable in terms of the fauna studied. They satisfy the quantitative criteria of a local biocorridor (except for Site No. 14) and can function as the elements of a local TSES as well as a part of the local biocorridors.

This habitat is linked with a forest ecosystem, which is surrounded by meadow communities with a high degree of ecological stability, and a diversity index as well as feeding or melliferous potential (Site No. 15). The site also fulfils the criteria of a local biocorridor and thus can be a part of a local TSES and a local biocorridor.

The other vegetation lines assessed, i.e., mostly regionally valuable tree-lines and blackthorn shrubbery, were assigned medium- to- low significance values. Some of the lines evaluated are linked to forest stands or other linear NFWV formations (Site Nos. $1,4,5,6$ and 7) surrounded by meadow cover.

Many of these lines occur on slopes and arable land, where the erosive soil removal rate (according to the erosion models) exceeds the limit values for a certain soil depth and are mostly isolated (Site Nos. 3, 8, 9, 11, 12 and 17).

However, they do not meet the qualitative criteria for the delineation of local corridors (a minimum length of less than $15 \mathrm{~m}$ ). In a local TSES, they can function as interactive elements, which are necessary or important when performing an anti-erosion function.

\section{Discussion}

The structure of the landscape of the model territory is remarkable for its ecologically significant linear biotic elements with trees representing local TSES elements, i.e., biocorridors, interaction points, and anti-erosion elements. It is largely influenced by fruit growing and a viniculture, which was introduced into this territory from the region of Krupina. The whole Krupina region ranks among the most productive fruit-growing and viniculture regions due to its natural predispositions and favourable slope orientation (south, south-west or west) (Jančová, 1986). The most important fruit species include plums, pears, apples and especially cherries. So far, nine cherry, 14 plum, seven pear, and 18 apple varieties have been recorded in the territory (Vachold, 1998; Ištvánová, 2012). In the old orchards and avenues, species still grow which are typical of a wine-growing region, e.g., Sorbus domestica, Morus nigra, Mespilus germanica and Castanea sativa. Species such as Castanea sativa or Mespilus germanica reach their northern distribution limit in the former district of Zvolen and climb to an altitude of $450 \mathrm{~m}$ a. s. 1. (Benčat', 1982). The occurrence of Mespilus germanica in the study areas was documented at an altitude of $530 \mathrm{~m}$ a. s. 1. (Site No. 19). Many writers have pointed out the need to protect old fruit trees in the region because of their importance, status and functions (Jančová, 1998; Brodianska, 1999).

A bocage, a landscape with a network of tree lines which act as elements that fulfill a range of diverse functions, has been developing and changing over many centuries and is considered today as a sustainable landscape element; and thus a special system of management should be adopted in these cases (Matějka, 2010).

The range of changes in the properties and functions of linear formations should be discussed on the European and international levels. They should function as an impetus for preserving measures to identify rare or threatened parts of a landscape. This is a major task for scientists, policymakers, and planners (Baudry et al., 2000). 
The determinations of the landscape-ecological and biotic (significance of a habitat) significance were based on a multi-criteria evaluation, which enables a prompt comparison of the results of individual habitats, although it may seem that it results in a simplification of the results, a loss of information, and neglect of the relations between the variables and the final value. Therefore, it is crucial to interpret the results even further (Špulerová, 2004). The topic of the multi-criteria evaluation of NFWV has been studied by many writers (Sláviková, 1987; Jurko, 1990; Halada, 1998; Špulerová, 2004, etc.). Landscape-ecological significance $\left(\mathrm{V}_{\mathrm{ke}}\right)$ was definedby applying seven (7) criteria (Jurko, 1990), which reflect the values of the habitats concerned. It can be assumed that the feeding potential might have influenced the final values of $\mathrm{V}_{\mathrm{ke}}$. The same can be claimed regarding the melliferous potential. It is highly likely that stability is a very important factor affecting the final value $\mathrm{V}_{\mathrm{ke}}$.

Based on the aforementioned results and the conclusions reached by other writers, the biotic habitat significance $\mathrm{V}_{\text {bio }}$ was evaluated by applying the following criteria: diversity of plant and animal species, minimum width, surrounding habitats, layering, and connectivity with other formations. The diversity values for animal and plant species did not differ considerably within the study area, but in the case of a 3-point scale, they might have affect the final value $\mathrm{V}_{\text {bio. }}$. The vertical stratification, however, did not influence the final value as all the lines assessed included all the vegetation layers. It is highly likely that the results were most significantly affected by the minimum width, surrounding habitats, and connectivity with other formations.

In the study area, the incidence and cover of the vegetation species in the linear formations of NFWV were influenced not only by the environmental properties (soil type, altitude, orientation, geological substrate), but also by the data from the phytocoenological surveys such as the minimum length of the line and the $\mathrm{E}_{2}$ and $\mathrm{E}_{3}$ covers.

Several other writers have arrived at the same results (e.g., Royand Blois, 2008) and argue that the incidence of species, abundance and diversity of plant species of linear corridors increases with their width, overlapping of their main vegetation layer, and dependence on the soil properties. Špulerová (2004) claims that the richness and coverage of plant species depend on the type of soil, inclination and the cover of $\mathrm{E}_{1}, \mathrm{E}_{2}, \mathrm{E}_{3}$ layers.

In the case of NFWV in the cadastre of Žibritov, the key factors for the structure of the animal species inhabiting the territory are the width of the line and the connectivity and character of any adjacent habitats. This has been confirmed by RDA analyses of bird communities and selected groups of macroedaphones as well as field observations of higher vertebrates. Signs of the presence of these animals have been detected almost exclusively in formations which were linked with surrounding forest habitats or which created a network of NFWV formations.

\section{Conclusions}

NFWV is a very important element of a landscape. In almost every area-based territorial plan, in studies of TSES at different hierarchical levels, in rural development and village renewal plans, and in hydro-ecological plans, it is recommended to maintain and restore NFWV and the ecological stability of an agricultural landscape through the protection and restoration of the network of eco-stabilizing elements. When designing plantings or modifications to existing vegetation, it is essential to consider the functions of vegetation. Without that consideration, landscaping alterations would not be comprehensive. 
The nature conservation, anti-erosion, biotic and landscape-ecological significance of vegetation has a vital impact on the overall ecological assessment of an area, which is particularly used for judging the ecological stability of a landscape. To achieve stability, the appropriate representation and distribution of cultural and natural communities is of great importance.

An assessment of the current ecological (health) condition of a landscape is mostly aimed at the elements of the primary and secondary landscape structure, which includes NFWV. In most cases, it involves a determination of the ecological stability, diversity, loads, balance, capacity and potential of vegetation. It also exploits interpretations of the formations of vegetation, their productive properties, functional characteristics and other special-purpose classifications of the biota. The interpretation is predominantly aimed at indicators such as the dynamics and degree of changes in the vegetation, the diversity of the vegetation, the vegetation cover, the degree of the synanthropy of the vegetation, the functional value of the vegetation, and the special-purpose characteristics of the vegetation, e.g., a determination of the importance of a particular function of the current vegetation, the classification of vegetation complexes in terms of their ability to perform certain functions on agricultural land, etc., the vertical and horizontal stability of the landscape, and the aesthetic effect as well as the perception of the landscape (Ružička, 2000). Such representations allow not only for an assessment of the current ecological state of a landscape, but also provide important arguments for the protection of the NFWV elements, which perform significant functions in the landscape and directly influence its potential.

These evaluations of vegetation, however, are not present in the methodologies of the terrestrial systems of ecological stability. Therefore, we decided to address this issue, so the output of the study presented is a proposal for monitoring the qualitative and quantitative properties of NFWV in the field mapping for TSES projects, as well as a proposal for the interpretations of the structural, ecological-habitat characteristics and special-purpose properties of vegetation, which could be further used in the projecting of TSES.

The results of the research, mapping and evaluation of the linear formations of NFWV can be summarized as follows:

- Riparian vegetation in alder floodplain forests had high values of landscapeecological and biotic significance in the model territory. They perform a full range of hydrological, climatic and refugial functions along with water management functions. Furthermore, fragments of Carpathian oak-hornbeam forests, blackthorn hazel shrubbery, blackthorn shrubbery and tree lines function as important ecostabilising elements in the countryside.

- The diversity of the structure and habitats of the landscape in the area of the Štiavnické vrchy mountains is affected by changes in land use caused by agriculture. The decline in the traditional uses and management of the land has significantly altered the physiognomic and ecological character of the landscape's structure (Jančová, 1998).

- In the model territory of the cadastre of Žibritov, which is a small picturesque village situated in a natural environment, some changes have taken place, although they are not dramatic ones. Although a network of regionally rare vegetation lines has been preserved here, they require special attention. They include tree lines with the presence of old fruit trees, which are the most important habitats for nature conservation. These habitats typically have a high 
diversity of species, perform compensatory (counterbalance the negative impact of human activity), utility and anti-erosion functions, and serve as a habitat for various plant and animal species by facilitating their migration and distribution. They provide shelter, a resting place and sources of food.

The results of the particular research demonstrate that the most valuable habitats include tree lines with mature fruit trees and exotic tree species. However, these habitats are threatened by the decline of older individuals; their health condition is affected by the occurrence of mistletoe; incidents of chlorosis and defoliation were detected. A lot of older varieties of tree species have properties superior to newer varieties (resistance to frost, animal pests or fungi). Fruit trees are beneficial elements. Moreover, they also fulfil aesthetic and recreational functions (the colour of their blossoms in the spring, the colour of their fruit in the autumn, relaxation). These functions, however, may pose problems because a habitat also provides a refuge for endangered plant and animal species. Unfortunately, many of the aforementioned old fruit species and rare varieties are withered, invaded by mistletoe, and are slowly dying off. Therefore, the implementation of a proposal for management and protection procedures might promote the cultural and ecological legacy of these rare tree lines.

According to the information available, there is a programme in progress called "Saving and preserving the gene pool of old and regional tree varieties in the region of Krupina". Therefore, we suggest including the territory studied in this programme, conducting a detailed inventory survey, and mapping the old varieties of fruit trees. Also, unwanted elements should be isolated, and we propose further management measures and monitoring.

Thorough research of NFWV and the consequently reliable interpretations of vegetation are a prerequisite for a highly successful development of TSES projects and other landscape-ecological documents and materials.

Acknowledgements. This paper was supported by the VEGA scientific grant agency, project No. 1/0096/16 and the KEGA cultural and educational grant agency, project No. 13TUZ-4/2016.

\section{REFERENCES}

[1] Arnold, G. W. (1983): The influence of ditch and hedgerow structure, length of hedgerows, and area of woodland and garden on bird numbers on farmland. - Journal of Applied Ecology 20: 731-750.

[2] Baudry, J. (1988): Hedgerows and Hedgerow Networks as Wildlife Habitat in Agricultural Landscapes. - In: Park, J. R. (ed.) Environmental Management in Agriculture. Belhaven Press, London.

[3] Baudry, J., Bunce, R. G. H., Burel, F. (2000): Hedgerows: An international perspective on their origin, function and management. - Journal of Environmental Management 60: 7-22.

[4] Benčat', F. (1982): Atlas rozšírenia cudzokrajných drevín na Slovensku a rajonizácia ich pestovania. Textová a mapová čast'. - VEDA, Slovak Academy of Sciences, Bratislava.

[5] Bennett, A. F. (1999): Linkages in the Landscape: The Role of Corridors and Connectivity in Wildlife Conservation. - IUCN, Gland, Switzerland and Cambridge.

[6] Brodianska, M. (1999): Krajinný ráz a ekosozologický význam podhoria CHKO Štiavnické vrchy v k.ú. Krupina. - Ph.D thesis. Technical University in Zvolen, Zvolen. 
[7] Bulír, P. (1981): Rekonstrukce a zakládání rozptýlené zeleně v zemědělské krajině. - In:

Štěpán, J. (ed.) Ekologie krajiny. Acta ecologica naturae ac regionis. Spoluvydavatel Terplan - Státní ústav pro územní plánování. Ministerstvo výstavby a techniky ČSR, Praha.

[8] Bulǐr, P. (1987): Inventarizace, evidence a pasportizace rozptýlené zeleně. - OBIS Výzkumný a šlechtitelský ústav okrasného zahradnictví, Průhonice.

[9] Burel, F. (1996): Hedgerows and their role in agricultural landscapes. - Critical Review in Plant Sciences 15:169-190.

[10] Cameron, R. A. D., Down, K., Pannett, D. J. (1980): Historical and environmental influences on hedgerow snail faunas. - Biological Journal of the Linnean Society 13: 7587.

[11] Čurlík, J., Šály, R. (2002): Typy pôd. - In: Miklós, L., Hrnčiarová, T. et al. (eds.) Atlas krajiny SR. MŽP SR, Bratislava, Esprit, s.r.o., Banská Štiavnica.

[12] Delattre, P., De Sousa, B., Fichet-Calvet, E., Qu'er'e, J. P., Giraudoux, P. (1999): Vole outbreaks in a landscape context: evidence from a 6-year study of Microtus arvalis. Landscape Ecology 14: 401-412.

[13] Forman, R. T. T., Baudry, J. (1984): Hedgerows and hedgerow networks in landscape ecology. - Environmental Management 8: 495-510.

[14] Forman, R. T. T., Godron, M. (1986): Lanscape Ecology. - John Wiley, New York.

[15] Green, R. E., Osborne, P. E., Sears, E. J. (1994): The distribution of passerine birds in hedgerows during the breeding season in relation to characteristics of the hedgerow and adjacent farmland. - Journal of Applied Ecology 31: 677-692.

[16] Halada, L. (1998): Krajinnoekologické hodnotenie vegetácie. - Ph.D Thesis. Institute of Landscape Ecology, Slovak Academy of Sciences, Nitra.

[17] Hinsley, S. A., Bellamy, P. E. (2000): The influence of hedge structure, management and landscape context on the value of hedgerows to birds: A review. - Journal of Environmental Management 60: 33-49.

[18] Hinsley, S. A., Bellamy, P. E., Sparks, T. H., Rothery, P. (1999): A Field Comparison of Habitat Characteristics and Diversity of Birds, Butterflies and Plants between Game and Nongame Areas. - In: Firbank, L. G. (ed.) Lowland Game Shooting Study. ITE, Cumbria.

[19] Hobbs, R. J. (1992): The role of corridors in conservation: solution or bandwagon? Trends in Ecology and Evolution 7: 389-392.

[20] Hudgens, B. R., Haddad, N. M. (2003): Predicting which species will benefit from corridors in fragmented landscapes from population growth model. - The American Naturalist 161(5): 808-820.

[21] Ištvánová, Z. (2012): Význam ovocných drevín v k.ú. Žibritov pre biodiverzitu krajiny a zachovanie starých a krajových odrôd. - Ph. D Thesis. Technical University in Zvolen, Zvolen.

[22] Jančová, G. (1986): Zachovajme krajinný charakter podhoria Štiavnických vrchoch. Chránené územia Slovenska 7: 46-48.

[23] Jančová G. (1998): Krajinná štruktúra CHKO Štiavnické vrchy v katastrálnom území Krupina a Žibritov. - Enviromagazín 3(1): 14-15.

[24] Johnson, R. J., Beck, M. M. (1988): Influences of shelterbelts on wildlife management and biology. - Agriculture, Ecosystems and Environment 22/23: 301-335.

[25] Jurko, A. (1990): Ekologické a socioekonomické hodnotenie vegetácie. - Príroda, Bratislava.

[26] Löw, J., et al. (1995): Rukovět' projektanta místního územního system ekologické stability. - Veronika, Brno.

[27] MacDonald, D. W., Johnson, P. J. (1995): The relationship between bird distribution and the botanical and structural characteristics of hedges. - Journal of Applied Ecology 32: $492-505$. 
[28] Machovec, J. (1994): Rozptýlená zeleň v krajine. - Vysoká škola zemědělská v Brně, Brno.

[29] Mann, C. C., Plummer, M. L. (1995): Are wildlife corridors the right path? - Science 270: $1428-1430$.

[30] Mareček, J. (2005): Krajinářská architektura venkovských sídel. - ČZU, Praha.

[31] Matějka, K. (2010): Ecotonal elements with woody species stand in the Bohemian forest landscape, their occurrence and classification. - Studia Oecologica 4: 15-28.

[32] Miklós, L., Diviaková, A., Izakovičová, Z. (2011): Ekologické siete a územné systémy ekologickej stability. - Technical University in Zvolen, Zvolen.

[33] Mind’áš, J., Škvarenina, J. (2002): Výskyt hmiel. - In: Miklós, L., Hrnčiarová T. et al. (eds.) Atlas krajiny SR. MŽP SR, Bratislava, Esprit, s.r.o., Banská Štiavnica.

[34] Opdam, P., Foppen, R., Reijnen, R., Schotman, A. (1995): The landscape ecological approach in bird conservation: integrating the metapopulation concept into spatial planning. - Ibis 137: 139-146.

[35] Osborne, P. (1984): Bird numbers and habitat characteristics in farmland hedgerows. Journal of Applied Ecology 21: 63-82.

[36] Rosenberg, D. K., Noon, B. R., Meslow, E. C. (1997): Biological corridors: form, function and efficacy. - BioScience 47: 677-687.

[37] Roy, V., Blois, S. (2008): Evaluating hedgerow corridors for the conservation of native forest herb diversity. - Biological Conservation 141: 298-307.

[38] Ružička, M. (2000): Krajinnoekologické plánovanie LANDEP. (Systémový prístup v krajinnej ekológii). - Biosféra, Zv. 1, Bratislava.

[39] Saunders, D. A., Hobbs, R. J. (eds.) (1991): Nature Conservation 2: The Role of Corridors. - Surrey Beatty and Sons, London.

[40] Shalaway, S. D. (1985): Fencerow management for nesting birds in Michigan. - Wildlife Society Bulletin 13: 302-306.

[41] Sláviková, D. (1987): Ochrana rozptýlenej zelene v krajine. - ÚV Slovenského zväzu ochrancov prírody a krajiny, Bratislava.

[42] Smith, D., Hellmund, P. C. (ed.) (1993): Ecology of Greenways, Design and Function of Linear Conseravtion Areas. - Univesity of Minesota Press, USA.

[43] Stašiov, S. (2006): Ekológia pôdnych organizmov (metódy výskumu mezo- až megazooedafónu). - Technical University in Zvolen, Zvolen.

[44] Šimo, E., Zat'ko, M. (2002): Typyrežimuodtoku. - In: Miklós, L., Hrnčiarová, T. et al. (eds.) Atlas krajiny SR. MŽP SR, Bratislava, Esprit s.r.o., BanskáŠtiavnica.

[45] Špulerová, J. (2004): Hodnotenie nelesnej drevinno-bylinnej vegetácie pre potreby krajinnoekologického plánovania. - PhD Thesis. Institute of Landscape Ecology, Slovak Academy of Sciences, Bratislava.

[46] Ter Braak, C. J. F., Šmilauer, P. (1998): CANOCO reference manual and users guide to CANOCO for Windows. Software for canonical community ordination (version 4). Centre of Biometry, Wageningen.

[47] Vachold, J. (1998): Správa o stave genofondu starých domácích odrôd ovocia. Manuscript, Banská Štiavnica. 